\begin{tabular}{cl|l}
$\begin{array}{c}\text { Cellular Physiology } \\
\text { and Biochemistry }\end{array}$ & Cell Physiol Biochem 2012;30:282-294 & \multicolumn{2}{l}{ DOI: 10.1159/000339064 } & $\begin{array}{l}\text { O 2012 S. Karger AG, Basel } \\
\text { www.karger.com/cpb }\end{array}$ \\
\cline { 2 - 3 } & $\begin{array}{l}\text { Published online: June 19, 2012 } \\
\text { Accepted: June 04, 2012 }\end{array}$ & $1015-8987 / 12 / 0301-0282 \$ 38.00 / 0$
\end{tabular}

\title{
Tanshinone IIA Stimulates Erythrocyte Phosphatidylserine Exposure
}

\author{
Christine Zelenak ${ }^{1} \quad$ Venkanna Pasham ${ }^{1} \quad$ Kashif Jilani $^{1} \quad$ Paola M. Tripodi $^{2}$ Luisa \\ Rosaclerio $^{2}$ Ganesh Pathare ${ }^{1}$ Adrian Lupescu ${ }^{1}$ Caterina Faggio ${ }^{2}$ Syed M. Qadri ${ }^{1}$ \\ Florian Lang ${ }^{1}$
}

${ }^{1}$ Department of Physiology, University of Tuebingen, Tuebingen, ${ }^{2}$ Department of Life Sciences "M. Malpighi" Section of General Physiology, University of Messina

\section{Key Words}

Phosphatidylserine $\cdot$ Cell membrane scrambling $•$ Calcium $•$ Cell volume $\bullet$ Eryptosis

\begin{abstract}
Tanshinone IIA, an antimicrobial, antioxidant, antianaphylactic, antifibrotic, vasodilating, antiatherosclerotic, organo-protective and antineoplastic component from the rhizome of Salvia miltiorrhiza, is known to trigger apoptosis of tumor cells. Tanshinone IIA is effective in part through mitochondrial depolarization and altered gene expression. Erythrocytes lack mitochondria and nuclei but may undergo eryptosis, an apoptosis-like suicidal cell death characterized by cell shrinkage and cell membrane scrambling with phosphatidylserine exposure at the cell surface. Eryptosis is triggered by increase of cytosolic $\mathrm{Ca}^{2+}$ activity, ATP depletion and ceramide formation. The present study explored, whether tanshinone IIA elicits eryptosis. Cytosolic $\mathrm{Ca}^{2+}$-concentration was determined from Fluo3-fluorescence, cell volume from forward scatter, phosphatidylserine exposure from binding of fluorescent annexin $V$, hemolysis from hemoglobin concentration in the supernatant, ATP concentration utilizing luciferin-luciferase and ceramide formation utilizing fluorescent anticeramide antibodies. Clearance of circulating erythrocytes was estimated by CFSE-labeling. A $48 \mathrm{~h}$ exposure to tanshinone IIA $(\geq 10 \mu \mathrm{M})$ significantly increased cytosolic $\mathrm{Ca}^{2+}$-concentration, decreased ATP concentration $(25 \mu \mathrm{M})$, increased lactate concentration $(25 \mu \mathrm{M})$, increased ceramide formation $(25 \mu \mathrm{M})$, decreased forward scatter, increased annexin-V-binding and increased (albeit to a much smaller extent) hemolysis. The effect of $25 \mu \mathrm{M}$ tanshinone IIA on annexin-V binding was partially reversed in the nominal absence of $\mathrm{Ca}^{2+}$. Labelled tanshinone IIA-treated erythrocytes were more rapidly cleared from the circulating blood in comparison to untreated erythrocytes. The present observations reveal a completely novel effect of tanshinone IIA, i.e. triggering of $\mathrm{Ca}^{2+}$ entry, ATP depletion and ceramide formation in erythrocytes, events eventually leading to eryptosis with cell shrinkage and cell membrane scrambling.
\end{abstract}

Copyright $\odot 2012$ S. Karger AG, Base 


\begin{tabular}{|c|c|c|}
\hline Collular Phvs & Cell Physiol Biochem 2012;30:282-294 & \\
\hline and Biochemistry & $\begin{array}{l}\text { DOI: } 10.1159 / 000339064 \\
\text { Published online: June 19, } 2012\end{array}$ & $\begin{array}{l}\text { (C) } 2012 \text { S. Karger AG, Basel } \\
\text { www.karger.com/cpb }\end{array}$ \\
\hline
\end{tabular}

\section{Introduction}

Tanshinone IIA (MW 294) [1] from the rhizome of Salvia miltiorrhiza [2, 3] is an active ingredient of Danshen, a well-known traditional Chinese medicine used for multiple therapeutic purposes [3] including cardiovascular diseases, such as coronary heart disease and stroke [4-6] as well as antitumor activity [7]. Efficacy of tanshinone IIA has been demonstrated both in vitro and in vivo $[3,8]$.

Tanshinone possesses antimicrobial [9, 10], antioxidant [11, 12], antianaphylactic [13], antifibrotic [14], vascular [5, 15, 16], antiatherosclerotic [17], cardioprotective [11, 12, 18, 19], pulmonary protective [20-22], renoprotective [23], bone protective [24], neuroprotective [12, 25-27] and antineoplastic [28-31] activities.

The antineoplastic effect of tanshinone IIA results from induction of apoptosis, as shown in cells derived from ovarian cancer [29], prostate cancer [28,30] and acute promyelocytic leukemia [31]. Beyond that tanshinone may induce hepatic stellate cell apoptosis [32] On the other hand, tanshinone IIA has been shown to inhibit apoptosis of cardiomyocytes $[11,33]$. The effect of tanshinone IIA involves mitochondria [34], altered gene expression [35], $\mathrm{Ca}^{2+}$ mobilisation and $\mathrm{Ca}^{2+}$ influx [36].

Similar to apoptosis of nucleated cells, eryptosis, the suicidal death of erythrocytes, leads to cell membrane scrambling and cell shrinkage [37]. As erythrocytes lack mitochondria and nuclei, eryptosis is independent from mitochondrial dysfunction and altered gene expression. Instead, eryptosis is triggered by $\mathrm{Ca}^{2+}$ entry through $\mathrm{Ca}^{2+}$-permeable cation channels [38, 39]. $\mathrm{Ca}^{2+}$ activates $\mathrm{Ca}^{2+}$-sensitive $\mathrm{K}^{+}$channels [40] with subsequent exit of $\mathrm{KCl}$ together with osmotically obliged water and thus cell shrinkage [41]. In addition, $\mathrm{Ca}^{2+}$ triggers cell membrane scrambling with subsequent exposure of phosphatidylserine at the cell surface [42]. $\mathrm{Ca}^{2+}$ further triggers cell membrane scrambling [37]. The cell is sensitized to the eryptotic effects of $\mathrm{Ca}^{2+}$ by ceramide [43], which is generated by acid sphingomyelinase [44]. Eryptosis is further triggered by energy depletion [45]. Moreover, erythrocyte cell membrane scrambling may be triggered by caspases [46, 47], which are activated by oxidative stress but are not required for the effect of $\mathrm{Ca}^{2+}$ on cell membrane scrambling [42]. Erythrocyte survival may further be modulated by kinases involved in the signaling of apoptosis, such as p38 MAPK and CK1 [48, 49].

The present study explored, whether tanshinone IIA influences cytosolic $\mathrm{Ca}^{2+}$ activity, cell volume and cell membrane scrambling of human erythrocytes and thus the programmed cell death of erythrocytes.

\section{Materials and Methods}

Erythrocytes, solutions and chemicals

Leukocyte-depleted erythrocytes were kindly provided by the blood bank of the University of Tübingen. The study is approved by the ethics committee of the University of Tübingen (184/2003V). Erythrocytes were incubated in vitro at a hematocrit of $0.4 \%$ in Ringer solution containing (in $\mathrm{mM}$ ) 125 $\mathrm{NaCl}, 5 \mathrm{KCl}, 1 \mathrm{MgSO}_{4}, 32 \mathrm{~N}$-2-hydroxyethylpiperazine-N-2-ethanesulfonic acid (HEPES), 5 glucose, $1 \mathrm{CaCl}_{2}$; $\mathrm{pH} 7.4$ at $37^{\circ} \mathrm{C}$ for $48 \mathrm{~h}$ with or without 1,10 or $25 \mu \mathrm{M}$ tanshinone IIA (purity > 98\%/TLC, Enzo Alexis). Where indicated, extracellular glucose was removed or tanshinone IIA (Enzo, Lörrach, Germany) added at the indicated concentrations. In $\mathrm{Ca}^{2+}$-free Ringer solution, $1 \mathrm{mM} \mathrm{CaCl}_{2}$ was substituted for $1 \mathrm{mM}$ glycolbis(2-aminoethylether)-N,N,N',N'-tetraacetic acid (EGTA).

FACS analysis of annexin-V-binding and forward scatter

After incubation under the respective experimental condition, $50 \mu \mathrm{l}$ cell suspension were washed in Ringer solution containing $5 \mathrm{mM} \mathrm{CaCl}_{2}$ and then stained with fluorescein-isothiocyanate (FITC)-conjugated Annexin-V (1:200 dilution; ImmunoTools, Friesoythe, Germany) in this solution at $37^{\circ} \mathrm{C}$ for 20 min under protection from light. In the following, the forward scatter (FSC) of the cells was determined, and annexin $\mathrm{V}$ fluorescence intensity was measured in FL-1 with an excitation wavelength of $488 \mathrm{~nm}$ and an emission wavelength of $530 \mathrm{~nm}$ on a FACS calibur (BD, Heidelberg, Germany). 


\begin{tabular}{|c|c|c|}
\hline $\mathrm{Col}$ & Cell Physiol Biochem 2012;30:282-294 & \\
\hline and Binchemistry & $\begin{array}{l}\text { DOI: } 10.1159 / 000339064 \\
\text { Published online: June 19, } 2012\end{array}$ & $\begin{array}{l}\text { O } 2012 \text { S. Karger AG, Basel } \\
\text { www.karger.com/cpb }\end{array}$ \\
\hline
\end{tabular}

Measurement of intracellular $\mathrm{Ca}^{2+}$

After incubation $50 \mu$ l suspension erythrocytes were washed in Ringer solution and then loaded with Fluo-3/AM (Biotium, Hayward, USA) in Ringer solution containing $5 \mathrm{mM} \mathrm{CaCl}_{2}$ and $2 \mu \mathrm{M}$ Fluo-3/AM. The cells were incubated at $37^{\circ} \mathrm{C}$ for $30 \mathrm{~min}$ and washed twice in Ringer solution containing $5 \mathrm{mM} \mathrm{CaCl}_{2}$. The Fluo-3/AM-loaded erythrocytes were resuspended in $200 \mu$ l Ringer. Then, $\mathrm{Ca}^{2+}$-dependent fluorescence intensity was measured in fluorescence channel FL-1 in FACS analysis.

\section{Determination of intracellular ATP concentration}

For determination of intracellular erythrocyte ATP, $90 \mu \mathrm{l}$ of erythrocyte pellets were incubated for 48 $\mathrm{h}$ at $37^{\circ} \mathrm{C}$ in Ringer solution with or without tanshinone IIA (final hematocrit $5 \%$ ). Additionally, erythrocytes were also incubated in glucose depleted Ringer solution as a positive control. All manipulations were then performed at $4^{\circ} \mathrm{C}$ to avoid ATP degradation. Cells were lysed in distilled water, and proteins were precipitated by addition of $\mathrm{HClO}_{4}(5 \%)$. After centrifugation, an aliquot of the supernatant ( $400 \mu \mathrm{l}$ ) was adjusted to $\mathrm{pH}$ 7.7 by addition of saturated $\mathrm{KHCO}_{3}$ solution. After dilution of the supernatant, the ATP concentrations of the aliquots were determined utilizing the luciferin-luciferase assay kit (Roche Diagnostics) on a luminometer (Berthold Biolumat LB9500, Bad Wildbad, Germany) according to the manufacturer's protocol. ATP concentrations are expressed in $\mathrm{mmol} / \mathrm{l}$ cytosol of erythrocytes.

\section{Determination of lactate generation}

For the determination of lactate formation, $200 \mu \mathrm{l}$ of erythrocyte pellets were incubated for $48 \mathrm{~h}$ at $37^{\circ} \mathrm{C}$ in Ringer solution with or without $25 \mu \mathrm{M}$ tanshinone IIA (final hematocrit $20 \%$ ). After $48 \mathrm{~h}$, the samples were centrifuged ( $3 \mathrm{~min}$ at $400 \mathrm{~g}$, room temperature) and the supernatant was collected. Total lactic acid content in the supernatant was measured by a commercial lactate assay kit (Bioassay systems) according to the manufacturer's instructions.

\section{Determination of ceramide formation}

For the determination of ceramide, a monoclonal antibody-based assay was used. After incubation with and without tanshinone IIA, cells were stained for $1 \mathrm{~h}$ at $37^{\circ} \mathrm{C}$ with $1 \mu \mathrm{g} / \mathrm{ml}$ anti-ceramide antibody (clone MID 15B4, Alexis, Grünberg, Germany) in PBS containing $0.1 \%$ bovine serum albumin (BSA) at a dilution of 1:5. The samples were washed twice with PBS-BSA. Subsequently, the cells were stained for 30 min with polyclonal fluorescein-isothiocyanate (FITC)-conjugated goat anti-mouse IgG and IgM specific antibody (Pharmingen, Hamburg, Germany) diluted 1:50 in PBS-BSA. Unbound secondary antibody was removed by repeated washing with PBS-BSA. The samples were then analysed by flow cytometric analysis in FL-1. As shown previously [44], the monoclonal antibody-based assay yields similar results as the biochemical determination of ceramide utilizing a diacylglycerol-kinase assay (Amersham Biosciences).

\section{Measurement of hemolysis}

For the determination of hemolysis the samples were centrifuged ( $3 \mathrm{~min}$ at $400 \mathrm{~g}$, room temperature) after incubation, and the supernatants were harvested. As a measure of hemolysis, the hemoglobin $(\mathrm{Hb})$ concentration of the supernatant was determined photometrically at $405 \mathrm{~nm}$. The absorption of the supernatant of erythrocytes lysed in distilled water was defined as $100 \%$ hemolysis.

\section{Confocal microscopy and immunofluorescence}

For the visualisation of eryptotic erythrocytes, $4 \mu \mathrm{l}$ of erythrocytes, incubated in respective experimental conditions, were stained with FITC-conjugated Annexin-V (1:100 dilution; ImmunoTools, Friesoythe, Germany) in $200 \mu$ l Ringer solution containing $5 \mathrm{mM} \mathrm{CaCl}_{2}$. Then the erythrocytes were washed twice and finally resuspended in $50 \mu \mathrm{l}$ of Ringer solution containing $5 \mathrm{mM} \mathrm{CaCl}_{2} .20 \mu$ were mounted with Prolong Gold antifade reagent (Invitrogen, Darmstadt, Germany) onto a glass slide, covered with a coverslip and images were subsequently taken on a Zeiss LSM 5 EXCITER confocal laser scanning microscope (Carl Zeiss MicroImaging, Oberkochen, Germany) with a water immersion Plan-Neofluar 63/1.3 NA DIC.

\section{Measurement of the in vivo clearance of fluorescence-labeled erythrocytes}

Following treatment with or without tanshinone IIA, erythrocytes (obtained from $200 \mu \mathrm{l}$ blood) were fluorescence-labeled by staining with $5 \mu \mathrm{M}$ carboxyfluorescein-diacetate-succinimidyl-ester (CFSE) (Molecular Probes, Leiden, Netherlands) in PBS and incubated for $30 \mathrm{~min}$ at $37^{\circ} \mathrm{C}$. After washing twice in PBS containing $1 \%$ FCS the pellet was resuspended in Ringer solution $\left(37^{\circ} \mathrm{C}\right)$, and $100 \mu \mathrm{l}$ of the CFSE-labeled erythrocytes were injected into the tail vein of the recipient mouse. After $36 \mathrm{~h}$, blood was retrieved from the tail veins of the mice, and CFSE-dependent fluorescence intensity of the erythrocytes was measured in FL-1 as described above. The percentage of CFSE-positive erythrocytes was calculated in \% of the total labeled fraction determined $5 \mathrm{~min}$ after injection. 


\section{Cellular Physiology $\quad$ Cell Physiol Biochem 2012;30:282-294

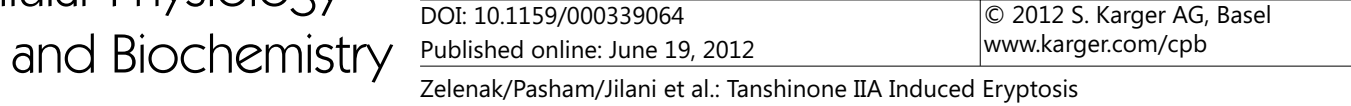

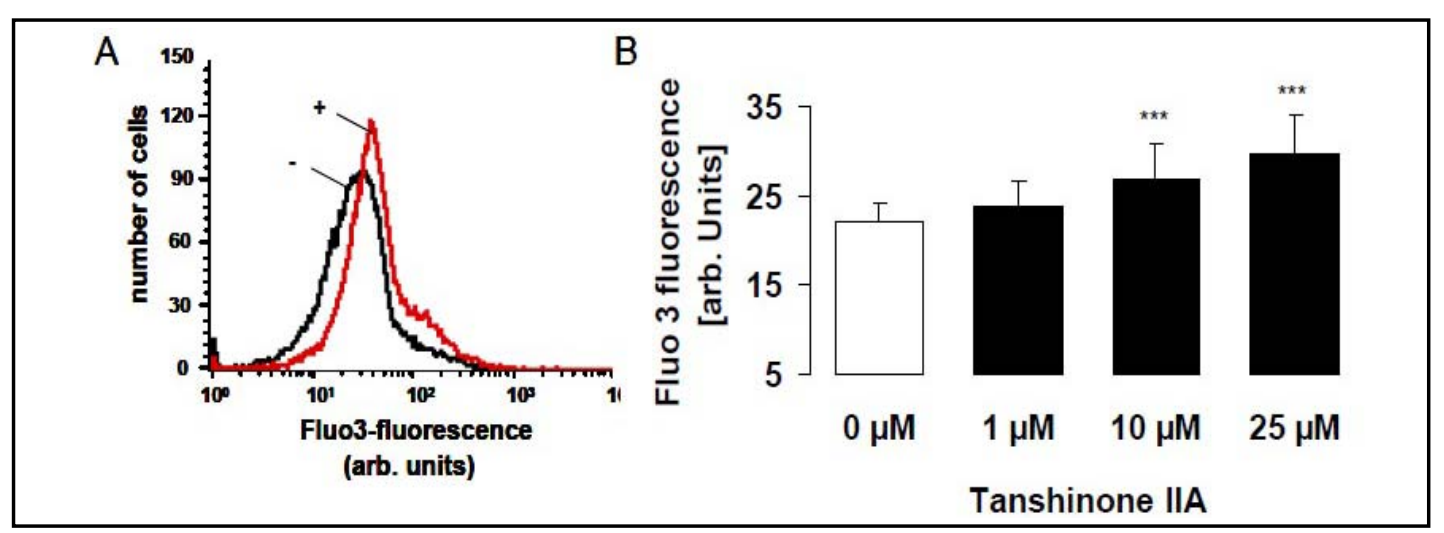

Fig. 1. Effect of tanshinone IIA on erythrocyte cytosolic $\mathrm{Ca}^{2+}$ concentration. A. Original histogram of Fluo3 fluorescence in erythrocytes following exposure for $48 \mathrm{~h}$ to Ringer solution without (-, black line) and with $(+$, red line) presence of $25 \mu \mathrm{M}$ tanshinone IIA. B. Arithmetic means \pm SD $(n=13)$ of the geo means (geometric mean of the histogram in arbitrary units) of Fluo3 -fluorescence in erythrocytes exposed for $48 \mathrm{~h}$ to Ringer solution without (white bar) or with (black bars) $1-25 \mu \mathrm{M}$ tanshinone IIA. ${ }^{* * *}(\mathrm{p}<0.001)$ indicates significant difference from the absence of tanshinone IIA (paired ANOVA).

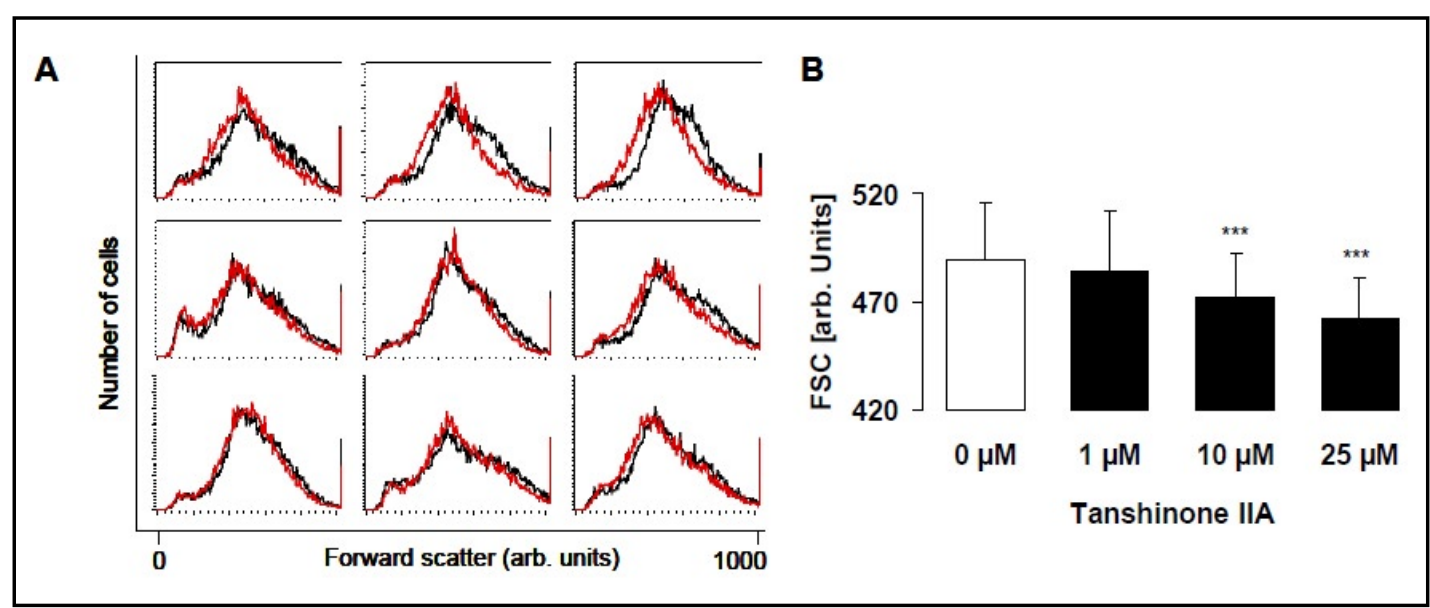

Fig. 2. Effect of tanshinone IIA on erythrocyte forward scatter. A. Original histograms of forward scatter of erythrocytes from 9 patients following exposure for $48 \mathrm{~h}$ to Ringer solution without (black lines) and with (red lines) presence of $25 \mu \mathrm{M}$ tanshinone IIA. B. Arithmetic means \pm SD $(n=13)$ of the erythrocyte forward scatter following incubation for $48 \mathrm{~h}$ to Ringer solution without (white bar) or with (black bars) 1-25 $\mu \mathrm{M}$ tanshinone IIA. ${ }^{* * *}(\mathrm{p}<0.001)$ indicates significant difference from the absence of tanshinone IIA (paired ANOVA).

\section{Statistics}

Data are expressed as arithmetic means \pm SD. Statistical analysis was made using paired ANOVA with Tukey's test as post-test, as appropriate. $n$ denotes the number of different erythrocyte specimens studied. Since different erythrocyte specimens used in distinct experiments are differently susceptible to eryptotic effects, the same erythrocyte specimens have been used for control and experimental conditions.

\section{Results}

To determine cytosolic $\mathrm{Ca}^{2+}$ concentration, Fluo 3-fluorescence was determined in FACS analysis. As shown in Fig. 1, treatment of human erythrocytes with tanshinone IIA resulted in an increase of Fluo3-fluorescence reflecting an increase of cytosolic $\mathrm{Ca}^{2+}$ concentration. The effect of tanshinone IIA on Fluo3-fluorescence reached statistical significance at a tanshinone IIA concentration of $10 \mu \mathrm{M}$. 


\begin{tabular}{ll|l} 
Cellular Physiology & \multicolumn{1}{c}{$\begin{array}{l}\text { Cell Physiol Biochem 2012;30:282-294 } \\
\text { and Biochemistry }\end{array}$} & $\begin{array}{l}\text { DOI: 10.1159/000339064 2012 S. Karger AG, Basel } \\
\text { www.karger.com/cpb }\end{array}$ \\
\cline { 2 - 3 } & $\begin{array}{l}\text { Published online: June 19, 2012 } \\
\text { Zelenak/Pasham/Jilani et al:: Tanshinone IIA Induced Eryptosis }\end{array}$
\end{tabular}

Fig. 3. Confocal images of PS-exposing erythrocytes with or without tanshinone IIA treatment. Confocal microscopy of FITC-dependent fluorescence (upper panels) and light microscopy (lower panels) of human erythrocytes stained with FITC-conjugated Annexin-V Fluos following $48 \mathrm{~h}$ incubation in Ringer solution without (left panels) and with (right panels) $25 \mu \mathrm{M}$ tanshinone IIA.
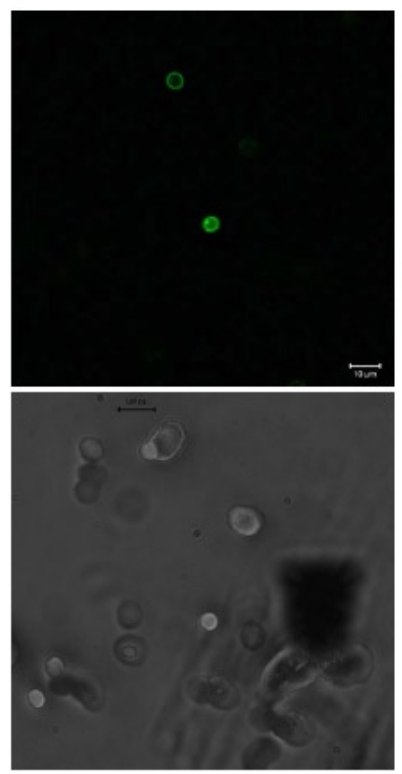

$0 \mu \mathrm{M}$
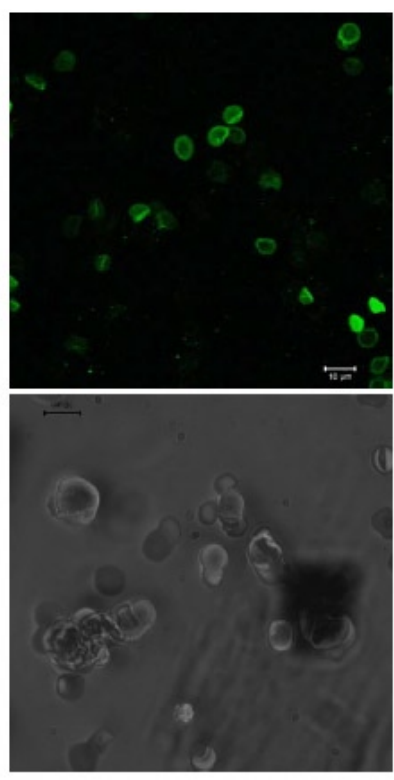

$25 \mu \mathrm{M}$

Tanshinone

$\mathrm{Ca}^{2+}$ is known to activate erythrocyte $\mathrm{Ca}^{2+}$ sensitive $\mathrm{K}^{+}$channels and an increase of cytosolic $\mathrm{Ca}^{2+}$ concentration is expected to trigger exit of $\mathrm{KCl}$ which, osmotically, obliges water to follow, an effect resulting in cell shrinkage. To determine the effect of tanshinone IIA on cell volume, forward scatter was determined in FACS analysis. As illustrated in Fig. 2, tanshinone IIA treatment was indeed followed by a decrease of forward scatter. The effect of tanshinone IIA on forward scatter reached statistical significance at a tanshinone IIA concentration of $10 \mu \mathrm{M}$.

$\mathrm{Ca}^{2+}$ is further known to trigger cell membrane scrambling with phosphatidylserine exposure at the cell surface. Phosphatidylserine exposing erythrocytes were identified utilizing annexin -V-binding. The fluorescent annexin-V-positive erythrocytes were visualized by confocal imaging. As shown in Fig. 3, a $48 \mathrm{~h}$ exposure to $25 \mu \mathrm{M}$ tanshinone IIA was followed by the appearance of annexin-V-positive erythrocytes, an observation pointing to the triggering of cell membrane scrambling.

Quantification of annexin-V-binding was accomplished by FACS analysis. As demonstrated in Fig. $4 \mathrm{~A}$ and $4 \mathrm{~B}$, a $48 \mathrm{~h}$ treatment with tanshinone IIA increased the percentage of annexin $\mathrm{V}$ binding erythrocytes, an effect reaching statistical significance at $10 \mu \mathrm{M}$ tanshinone IIA.

For determination of hemolysis hemoglobin release into the supernatant was quantified in erythrocytes exposed for $48 \mathrm{~h}$ to Ringer solution without or with 1-25 $\mu \mathrm{M}$ tanshinone IIA. As illustrated in Fig. 4B, tanshinone IIA treatment was followed by hemolysis, an effect reaching statistical significance at $10 \mu \mathrm{M}$ tanshinone IIA. The percentage of hemolytic erythrocytes remained, however, by far smaller than the percentage of annexin -V-binding erythrocytes.

Further experiments aimed to define the causal role of $\mathrm{Ca}^{2+}$ in the triggering of cell membrane scrambling by tanshinone IIA. Erythrocytes were exposed to tanshinone IIA either in the presence or in the nominal absence of extracellular $\mathrm{Ca}^{2+}$. As shown in Fig. 4C, the effect of tanshinone IIA on annexin-V-binding was blunted, but not fully abolished in the nominal absence of $\mathrm{Ca}^{2+}$. Instead, the annexin-V-binding was in the nominal absence of $\mathrm{Ca}^{2+}$ but presence of tanshinone IIA significantly lower than the respective value in the presence of both $\mathrm{Ca}^{2+}$ and tanshinone IIA, but at the same time significantly higher than the respective value in the absence of tanshinone IIA in both, the presence or absence, of $\mathrm{Ca}^{2+}$. The effect of tanshinone IIA on cell membrane scrambling is thus in part due to an increase of intracellular $\mathrm{Ca}^{2+}$ activity. 


\begin{tabular}{ll|l} 
Cellular Physiology & \multicolumn{1}{c}{$\begin{array}{l}\text { Cell Physiol Biochem 2012;30:282-294 } \\
\text { and Biochemistry }\end{array}$} & $\begin{array}{l}\text { DOI: 10.1159/000339064 2012 S. Karger AG, Basel } \\
\text { aublished online: June 19, 2012 }\end{array}$ \\
\cline { 2 - 3 } & Zelenak/Pasham/Jilani et al:: Tanshinone IIA Induced Eryptosis
\end{tabular}

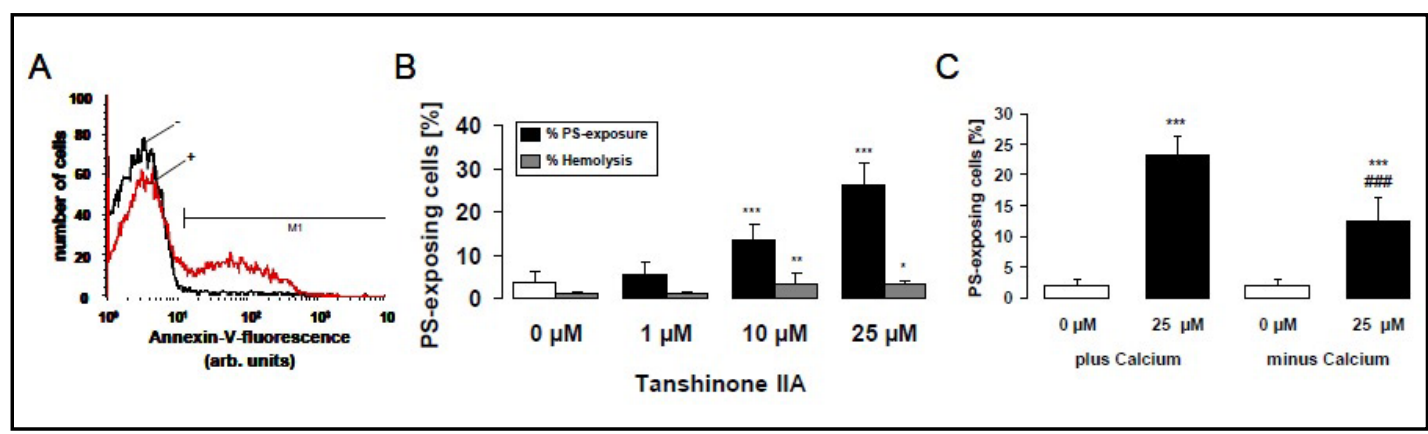

Fig. 4. Effect of tanshinone IIA on phosphatidylserine exposure and hemolysis. A. Original histogram of annexin-V-binding of erythrocytes following exposure for $48 \mathrm{~h}$ to Ringer solution without (-, black line) and with $(+$, red line) presence of $25 \mu \mathrm{M}$ tanshinone IIA. B. Arithmetic means \pm SD $(n=13)$ of erythrocyte annexin- V-binding following incubation for $48 \mathrm{~h}$ to Ringer solution without (white bar) or with (black bars) presence of 1-25 $\mu \mathrm{M}$ tanshinone IIA. For comparison, arithmetic means \pm SD $(n=7)$ of the percentage of hemolysis is shown as grey bars. ${ }^{*}(\mathrm{p}<0.05),{ }^{* *}(\mathrm{p}<0.01),{ }^{* *}(\mathrm{p}<0.001)$ indicates significant difference from the absence of tanshinone IIA (paired ANOVA). C. Arithmetic means \pm SD $(n=4)$ of the percentage of annexin-V-binding erythrocytes after a $48 \mathrm{~h}$ treatment with Ringer solution without (white bar) or with (black bars) $25 \mu \mathrm{M}$ tanshinone IIA in the presence (left bars, $+\mathrm{Ca}^{2+}$ ) and absence (right bars, $-\mathrm{Ca}^{2+}$ ) of calcium. *** $(\mathrm{p}<0.001)$ indicates significant difference from the absence of tanshinone IIA (paired ANOVA), \#\#\# $(\mathrm{p}<$ 0.001 ) indicates significant difference from the respective values in the presence of $\mathrm{Ca}^{2+}$.
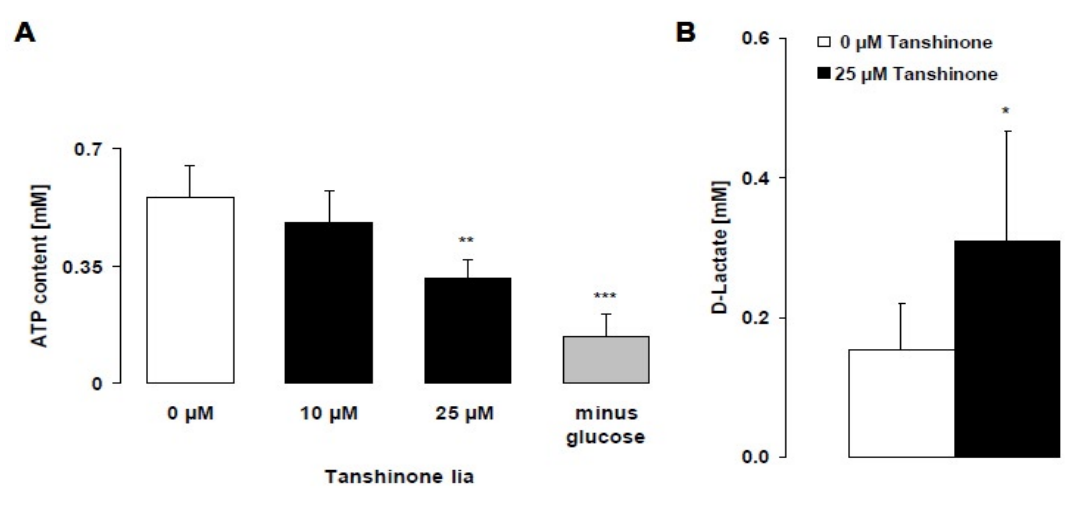

Fig. 5. Effect of tanshinone IIA on erythrocyte cytosolic ATP content and lactic acid release. A. Arithmetic means \pm SD $(n=4)$ of the ATP concentration after a $48 \mathrm{~h}$ incubation in Ringer solution without (white bar) or with (black bars) tanshinone IIA at the indicated concentrations, or in glucose-depleted Ringer solution (grey bar, minus glucose). ${ }^{* *}(p<0.01),^{* * *}(p<0.001)$ indicates significant difference from control (absence of tanshinone IIA and presence of glucose) (paired ANOVA). B. Tanshinone IIA-sensitive lactic acid formation in erythrocytes. Arithmetic means \pm SD $(n=6)$ of lactic acid formation in erythrocytes following incubation for $48 \mathrm{~h}$ in the absence (white bar) or presence (black bar) of $25 \mu \mathrm{M}$ tanshinone IIA. $*(\mathrm{p}<0.05)$ indicates significant difference from the absence of tanshinone II A (paired two-tailed t-test).

Further experiments were performed to possibly identify further mechanisms underlying the stimulating effect of tanshinone IIA on cell membrane scrambling. Known triggers of eryptosis include energy depletion. Accordingly, the effect of tanshinone IIA treatment on cytosolic ATP concentration was determined. As illustrated in Fig. 5a, the cytosolic ATP concentration was significantly lower in erythrocytes incubated for $48 \mathrm{~h}$ in Ringer containing tanshinone IIA than in erythrocytes exposed for $48 \mathrm{~h}$ in Ringer without tanshinone IIA. The effect of tanshinone IIA reached statistical significance at $25 \mu \mathrm{M}$ tanshinone IIA concentration. For comparison, the ATP concentration was determined in erythrocytes exposed to glucosefree Ringer. As shown in Fig. 5a, glucose depletion was followed by a more profound decrease of ATP concentration than the treatment with tanshinone IIA. 
Fig. 6. Effect of tanshinone IIA on ceramide formation. A. Original histograms of ceramide abundance in erythrocytes from 5 patients following exposure for $48 \mathrm{~h}$ to Ringer solution without (black lines) and with (red lines) presence of $25 \mu \mathrm{M}$ tanshinone IIA. B. Arithmetic means \pm SD (n $=5$ ) of ceramide abundance in erythrocytes following incubation for $48 \mathrm{~h}$ to Ringer solution without (white bar) or with (black bar) presence of $25 \mu \mathrm{M}$ tanshinone IIA. $*(\mathrm{p}<0.05)$ indicates significant difference from the absence of tanshinone IIA (paired ANOVA).

A

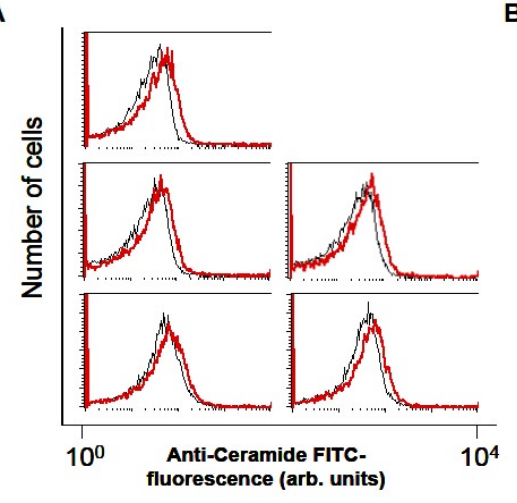

B

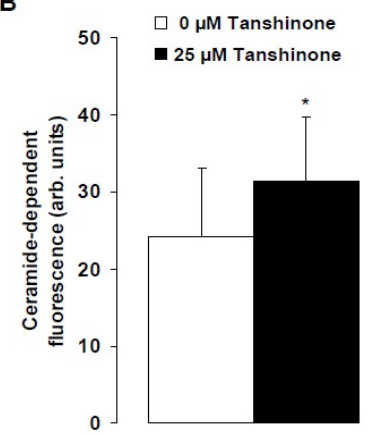

As the cytosolic ATP concentration was decreased by tanshinone IIA, the production of lactic acid was examined. As shown in Fig. 5b, the concentration of lactic acid in the supernatant of erythrocytes incubated for $48 \mathrm{~h}$ in Ringer containing $25 \mu \mathrm{M}$ tanshinone IIA was significantly higher than in erythrocytes exposed for $48 \mathrm{~h}$ in Ringer without tanshinone IIA.

Cell membrane scrambling is further known to be triggered by ceramide. Accordingly, FITC-labelled anticeramide antibodies were employed to analyse the effect of tanshinone IIA on ceramide abundance in the erythrocyte cell membrane. As shown in Fig. 6, tanshinone IIA $(25 \mu \mathrm{M})$ treatment indeed significantly increased ceramide abundance indicating that tanshinone IIA stimulates ceramide formation.

To elucidate whether tanshinone IIA influenced the in vivo life span of erythrocytes, erythrocytes were isolated from blood drawn from wild type mice, treated with tanshinone IIA $(25 \mu \mathrm{M})$ for $12 \mathrm{~h}$, labeled with the fluorescent dye CFSE, and subsequently injected into the tail vein of the same mice. The clearance of CFSE-labeled erythrocytes from the circulation was determined $36 \mathrm{~h}$ after reinjection. As a result tanshinone II A treatment significantly ( $\mathrm{p}<$ 0.05 ) accelerated the clearance of erythrocytes from circulating blood. The percentage of CSFE labelled erythrocytes remaining in circulating blood after $36 \mathrm{~h}$ was $56 \pm 15 \%(\mathrm{n}=3)$ without treatment and $13 \pm 1 \%(\mathrm{n}=3)$ with tanshinone IIA treatment.

\section{Discussion}

The present observations reveal a completely novel effect of tanshinone IIA, i.e. the stimulation suicidal erythrocyte death or eryptosis, which is characterized by cell membrane scrambling and cell shrinkage. The concentrations triggering eryptosis are within the range of tanshinone IIA plasma concentrations presumably approached in vivo. In mice, a dosages of $3-100 \mathrm{mg} / \mathrm{kg}$ tanshinone IIA have been administrated [12, 22, 50-55]. Following the application of $8 \mathrm{mg} / \mathrm{kg}$, the plasma concentration increased up to some $3 \mu \mathrm{M}$ [1]. The eryptosis is paralleled by hemolysis, which affects, however, only a comparably small percentage of erythrocytes.

The effect of tanshinone IIA on cell membrane scrambling is partially due to increase of cytosolic $\mathrm{Ca}^{2+}$ activity, which is known to trigger erythrocyte membrane scrambling [42, 46, 56]. According to indirect evidence, tanshinone IIA rather decreases $\mathrm{Ca}^{2+}$ entry into vascular smooth muscle cells. The channels involved remained elusive. In erythrocytes, $\mathrm{Ca}^{2+}$ entry presumably involves TRPC6 [38]. 


\section{Cellular Physiology Cell Physiol Biochem 2012;30:282-294

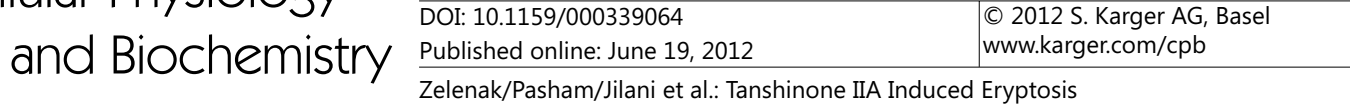

The incomplete inhibition of tanshinone IIA -induced cell membrane scrambling under $\mathrm{Ca}^{2+}$-depleted conditions prompted us to search for the effect of tanshinone on further mechanisms known to trigger eryptosis. Those mechanisms include energy depletion [45]. As a result, tanshinone IIA indeed decreases cytosolic ATP concentration. This effect is again moderate and contributes to but does not fully account for the strong stimulation of cell membrane scrambling. Erythrocyte ATP generation is dependent on glycolysis and the effect of tanshinone IIA on cytosolic ATP levels could have reflected an interference with glycolytic flux. Tumor cells gain their energy mainly from glucose degradation [57] and in theory impaired glycolysis could contribute to the known [28-31, 58] antineoplastic effect of tanshinone. However, lactic acid production was increased following incubation with $25 \mu \mathrm{M}$ tanshinone IIA. Thus, glycolytic flux appears to be enhanced by tanshinone IIA treatment and the substance presumably decreases cytosolic ATP levels by increasing ATP utilization.

Cell membrane scrambling is further stimulated by ceramide $[43,59]$. Again, tanshinone IIA moderately increases ceramide abundance, an effect contributing to but not fully accounting for the stimulation of cell membrane scrambling.

Beyond its effect of cell membrane scrambling $\mathrm{Ca}^{2+}$ activates $\mathrm{Ca}^{2+}$ sensitive $\mathrm{K}^{+}$channels $[40,60]$ with resulting $\mathrm{K}^{+}$exit, cell membrane hyperpolarisation, $\mathrm{Cl}^{-}$exit and thus cellular loss of water [41]. Tanshinone IIA indeed decreases the forward scatter, an observation pointing to cell shrinkage. In nucleated cells tanshinone has been shown to activate several types of $\mathrm{K}^{+}$ channels $[16,20,61]$, which would similarly hyperpolarize the cell membrane, increase the electrical driving force for $\mathrm{Cl}^{-}$exit and thus result in cellular $\mathrm{KCl}$ loss. On the other hand, tanshinone has been shown to downregulate aquaporins [21], which would impede water fluxes and thus cell volume changes.

Signaling involved in the effects of tanshinone IIA in nucleated cells further includes Akt-GSK-3 $\beta$ [19, 22, 30, 62], p38 kinase [6, 29], NFKB [35], calreticulin [63], caspase 12 [63] and GADD153 [63], inhibition of mitochondria permeability transition [34], cytochromes P450 1A1 and 1A2 [64], CYP3A2 and CYP2C11 [65], nitric oxide [5, 36], prostaglandin E2, CD40 [66] and matrix metalloproteinase-2 (MMP-2) activity [66]. At least in theory, some of those mechanisms may contribute to the stimulation of eryptosis. In any case, most of the effect of tanshinone IIA on eryptosis is explained by $\mathrm{Ca}^{2+}$ entry, ceramide formation and ATP depletion.

Tanshinone IIA sensitivity may be enhanced in clinical disorders associated with increased eryptosis-susceptibility of erythrocytes [37], such as iron deficiency [67], phosphate depletion [68], Hemolytic Uremic Syndrome [69], sepsis [70], sickle cell disease [71], malaria [7276], APC gene mutation [77] Wilson's disease [76] and possibly metabolic syndrome [78]. Tanshinone IIA may further potentiate the eryptotic effect of other eryptosis triggering xenobiotics [48, 72, 79-92]. Accelerated eryptosis may lead to anemia [37] and adherence of phosphatidylserine-exposing erythrocytes to the vascular wall with the respective impairment of microcirculation [93-97]. Eryptotic erythrocytes are further known to stimulate blood clotting $[93,98,99]$.

The present observations may be relevant not only for erythrocytes but similarly effective in nucleated cells. To the best of our knowledge, an effect of tanshinone on ceramide formation has never been reported, but possibly, ceramide similarly participates in the effects of tanshinone IIA on apoptosis, as ceramide is well known to trigger apoptosis in a variety of cells [100]. In nucleated cells, tanshinone influences apoptosis in part by inhibition of mitochondria permeability transition [34], a mechanism, which cannot be operative in erythrocytes. In nucleated cells, tanshinone IIA is further partially effective through inhibition of the transcription factor NFKB [35]. Again, transcription cannot contribute to suicidal death of mature, nuclei lacking erythrocytes. Interestingly, though, NFkB inhibitors Bay 11-7082 and Parthenolide similarly trigger eryptosis [85], an effect which may, however, not be related to NFKB inhibition. 


\section{Cellular Physiology Cell Physiol Biochem 2012;30:282-294 \\ \begin{tabular}{ll|l} 
and BiOChemistry & $\begin{array}{l}\text { DOI: 10.1159/000339064 } \\
\text { Published online: June 19, } 2012\end{array}$ & $\begin{array}{l}\text { (c) 2012 S. Karger AG, Basel } \\
\text { www.karger.com/cpb }\end{array}$ \\
\cline { 2 - 3 } & Zelenak/Pasham/Jilani et al.: Tanshinone IIA Induced Eryptosis
\end{tabular}}

In conclusion, the present study reveals a completely novel effect of tanshinone IIA, i.e. the $\mathrm{Ca}^{2+}$ entry, ATP depletion despite enhanced glycolysis, and ceramide formation in erythrocytes, which collectively stimulate cell membrane scrambling and cell shrinkage followed by clearance of the affected erythrocytes from circulating blood.

\section{Acknowledgements}

The authors acknowledge the meticulous preparation of the manuscript by Sari Rübe, Lejla Subasic and Ali Soleimanpour. This study was supported by the Deutsche Forschungsgemeinschaft.

\section{References}

1 Guo ZJ, Zhang Y, Tang X, Li H, Sun QS: Pharmacokinetic interaction between tanshinones and polyphenolic extracts of salvia miltinorrhiza BUNGE after intravenous administration in rats. Biol Pharm Bull 2008;31:1469-1474.

2 Li MH, Chen JM, Peng Y, Wu Q, Xiao PG: Investigation of Danshen and related medicinal plants in China. J Ethnopharmacol 2008;120:419-426.

3 Wang X, Morris-Natschke SL, Lee KH: New developments in the chemistry and biology of the bioactive constituents of Tanshen. Med Res Rev 2007;27:133-148.

4 Liu JQ Lee TF, Miedzyblocki M, Chan GC, Bigam DL, Cheung PY: Effects of tanshinone IIA, a major component of Salvia miltiorrhiza, on platelet aggregation in healthy newborn piglets. J Ethnopharmacol 2011;137:4449.

5 Pan C, Lou L, Huo Y, Singh G, Chen M, Zhang D, Wu A, Zhao M, Wang S, Li J: Salvianolic acid B and Tanshinone IIA attenuate myocardial ischemia injury in mice by NO production through multiple pathways. Ther Adv Cardiovasc Dis 2011;

6 Zhang Y, Zhang L, Chu W, Wang B, Zhang J, Zhao M, Li X, Li B, Lu Y, Yang B, Shan H: Tanshinone IIA inhibits miR-1 expression through p38 MAPK signal pathway in post-infarction rat cardiomyocytes. Cell Physiol Biochem 2010;26:991-998.

7 Zhang Z, Zhang J, Jin L, Song T, Wu G, Gao J: Tanshinone IIA interacts with DNA by minor groove-binding. Biol Pharm Bull 2008;31:2342-2345.

8 Ho JW, Jie M: Pharmacological activity of cardiovascular agents from herbal medicine. Cardiovasc Hematol Agents Med Chem 2007;5:273-277.

9 Slusarczyk S, Zimmermann S, Kaiser M, Matkowski A, Hamburger M, Adams M: Antiplasmodial and Antitrypanosomal Activity of Tanshinone-Type Diterpenoids from Salvia miltiorrhiza. Planta Med 2011;-in press.

10 Zhao J, Lou J, Mou Y, Li P, Wu J, Zhou L: Diterpenoid Tanshinones and Phenolic Acids from Cultured Hairy Roots of Salvia miltiorrhiza Bunge and Their Antimicrobial Activities. Molecules 2011;16:2259-2267.

11 Fu J, Huang H, Liu J, Pi R, Chen J, Liu P: Tanshinone IIA protects cardiac myocytes against oxidative stresstriggered damage and apoptosis. Eur J Pharmacol 2007;568:213-221.

12 Yang L, Zhang B, Yin L, Cai B, Shan H, Zhang L, Lu Y, Bi Z: Tanshinone IIA prevented brain iron dyshomeostasis in cerebral ischemic rats. Cell Physiol Biochem 2011;27:23-30.

13 Trinh HT, Chae SJ, Joh EH, Son KH, Jeon SJ, Kim DH: Tanshinones isolated from the rhizome of Salvia miltiorrhiza inhibit passive cutaneous anaphylaxis reaction in mice. J Ethnopharmacol 2010;132:344-348.

14 Chunming J, Miao Z, Cheng S, Nana T, Wei Z, Dongwei C, Yuan F: Tanshinone IIA Attenuates Peritoneal Fibrosis through Inhibition of Fibrogenic Growth Factors Expression in Peritoneum in a Peritoneal Dialysis Rat Model. Ren Fail 2011;33:355-362.

15 Li X, Du JR, Yu Y, Bai B, Zheng XY: Tanshinone IIA inhibits smooth muscle proliferation and intimal hyperplasia in the rat carotid balloon-injured model through inhibition of MAPK signaling pathway. J Ethnopharmacol 2010;129:273-279. 


\section{Cellular Physiology Cell Physiol Biochem 2012;30:282-294

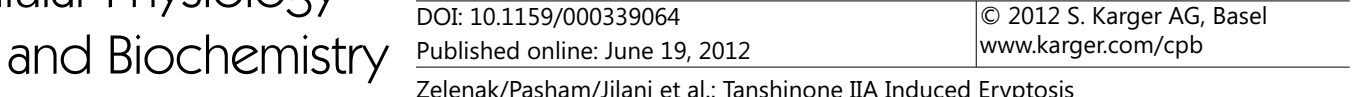 \\ Zelenak/Pasham/Jilani et al.: Tanshinone IIA Induced Eryptosis}

16 Tan X, Yang Y, Cheng J, Li P, Inoue I, Zeng X: Unique action of sodium tanshinone II-A sulfonate (DS-201) on the $\mathrm{Ca}(2+)$ dependent $\mathrm{BK}(\mathrm{Ca})$ activation in mouse cerebral arterial smooth muscle cells. Eur J Pharmacol 2011;656:27-32.

17 Tang FT, Cao Y, Wang TQ, Wang LJ, Guo J, Zhou XS, Xu SW, Liu WH, Liu PQ Huang HQ: Tanshinone IIA attenuates atherosclerosis in ApoE(-/-) mice through down-regulation of scavenger receptor expression. Eur J Pharmacol 2011;650:275-284.

18 Lu Y, Liu X, Liang X, Xiang L, Zhang W: Metabolomic strategy to study therapeutic and synergistic effects of tanshinone IIA, salvianolic acid B and ginsenoside Rb1 in myocardial ischemia rats. J Ethnopharmacol 2011;134:45-49.

19 Sun D, Shen M, Li J, Li W, Zhang Y, Zhao L, Zhang Z, Yuan Y, Wang H, Cao F: Cardioprotective effects of tanshinone IIA pretreatment via kinin B2 receptor-Akt-GSK-3beta dependent pathway in experimental diabetic cardiomyopathy. Cardiovasc Diabetol 2011;10:4.

20 Huang YF, Liu ML, Dong MQ, Yang WC, Zhang B, Luan LL, Dong HY, Xu M, Wang YX, Liu LL, Gao YQ, Li ZC: Effects of sodium tanshinone II A sulphonate on hypoxic pulmonary hypertension in rats in vivo and on Kv2.1 expression in pulmonary artery smooth muscle cells in vitro. J Ethnopharmacol 2009;125:436-443.

21 Li J, Xu M, Fan Q, Xie X, Zhang Y, Mu D, Zhao P, Zhang B, Cao F, Wang Y, Jin F, Li Z: Tanshinone IIA ameliorates seawater exposure-induced lung injury by inhibiting aquaporins (AQP) 1 and AQP5 expression in lung. Respir Physiol Neurobiol 2011;176:39-49.

22 Li JH, Xu M, Xie XY, Fan QX, Mu DG, Zhang Y, Cao FL, Wang YX, Zhao PT, Zhang B, Jin FG, Li ZC: Tanshinone IIA suppresses lung injury and apoptosis, and modulates protein kinase B and extracellular signal-regulated protein kinase pathways in rats challenged with seawater exposure. Clin Exp Pharmacol Physiol 2011;38:269277.

23 Ahn YM, Kim SK, Lee SH, Ahn SY, Kang SW, Chung JH, Kim SD, Lee BC: Renoprotective effect of Tanshinone IIA, an active component of Salvia miltiorrhiza, on rats with chronic kidney disease. Phytother Res 2010;24:18861892.

24 Liu YR, Qu SX, Maitz MF, Tan R, Weng J: The effect of the major components of Salvia Miltiorrhiza Bunge on bone marrow cells. J Ethnopharmacol 2007;111:573-583.

25 Liu T, Jin H, Sun QR, Xu JH, Hu HT: The neuroprotective effects of tanshinone IIA on beta-amyloid-induced toxicity in rat cortical neurons. Neuropharmacology 2010;59:595-604.

26 Shen JL, Chen YS, Lin JY, Tien YC, Peng WH, Kuo CH, Tzang BS, Wang HL, Tsai FJ, Chou MC, Huang CY, Lin CC: Neuron Regeneration and Proliferation Effects of Danshen and Tanshinone IIA. Evid Based Complement Alternat Med 2011;2011:378907.

27 Wang W, Zheng LL, Wang F, Hu ZL, Wu WN, Gu J, Chen JG: Tanshinone IIA attenuates neuronal damage and the impairment of long-term potentiation induced by hydrogen peroxide. J Ethnopharmacol 2011;134:147155.

28 Gong Y, Li Y, Lu Y, Li L, Abdolmaleky H, Blackburn GL, Zhou JR: Bioactive tanshinones in Salvia miltiorrhiza inhibit the growth of prostate cancer cells in vitro and in mice. Int J Cancer 2011;129:1042-1052.

29 Jiao JW, Wen F: Tanshinone IIA acts via p38 MAPK to induce apoptosis and the down-regulation of ERCC1 and lung-resistance protein in cisplatin-resistant ovarian cancer cells. Oncol Rep 2011;25:781-788.

30 Won SH, Lee HJ, Jeong SJ, Lee HJ, Lee EO, Jung DB, Shin JM, Kwon TR, Yun SM, Lee MH, Choi SH, Lu J, Kim SH: Tanshinone IIA induces mitochondria dependent apoptosis in prostate cancer cells in association with an inhibition of phosphoinositide 3-kinase/AKT pathway. Biol Pharm Bull 2010;33:1828-1834.

31 Zhang K, Li J, Meng W, Xing H, Yang Y: C/EBPbeta and CHOP participate in tanshinone IIA-induced differentiation and apoptosis of acute promyelocytic leukemia cells in vitro. Int J Hematol 2010;92:571578.

32 Elsharkawy AM, Oakley F, Mann DA: The role and regulation of hepatic stellate cell apoptosis in reversal of liver fibrosis. Apoptosis 2005;10:927-939.

33 Hong HJ, Liu JC, Cheng TH, Chan P: Tanshinone IIA attenuates angiotensin II-induced apoptosis via Akt pathway in neonatal rat cardiomyocytes. Acta Pharmacol Sin 2010;31:1569-1575.

34 Zhu B, Zhai Q Yu B: Tanshinone IIA protects rat primary hepatocytes against carbon tetrachloride toxicity via inhibiting mitochondria permeability transition. Pharm Biol 2010;48:484-487.

35 Jang SI, Kim HJ, Kim YJ, Jeong SI, You YO: Tanshinone IIA inhibits LPS-induced NF-kappaB activation in RAW 264.7 cells: possible involvement of the NIK-IKK, ERK1/2, p38 and JNK pathways. Eur J Pharmacol 2006;542:1-7. 


\section{Cellular Physiology Cell Physiol Biochem 2012;30:282-294

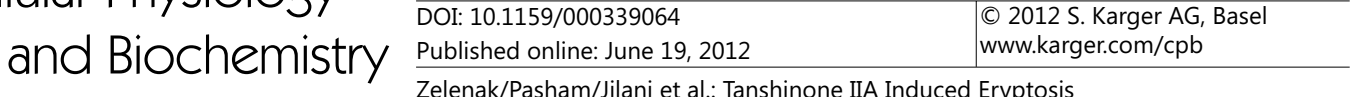 \\ Zelenak/Pasham/Jilani et al.: Tanshinone IIA Induced Eryptosis}

36 Fan G, Zhu Y, Guo H, Wang X, Wang H, Gao X: Direct Vasorelaxation by a Novel Phytoestrogen Tanshinone IIA Is Mediated by Nongenomic Action of Estrogen Receptor Through Endothelial Nitric Oxide Synthase Activation and Calcium Mobilization. J Cardiovasc Pharmacol 2011;57:340-347.

37 Lang F, Gulbins E, Lerche H, Huber SM, Kempe DS, Foller M: Eryptosis, a window to systemic disease. Cell Physiol Biochem 2008;22:373-380.

38 Foller M, Kasinathan RS, Koka S, Lang C, Shumilina E, Birnbaumer L, Lang F, Huber SM: TRPC6 contributes to the $\mathrm{Ca}(2+)$ leak of human erythrocytes. Cell Physiol Biochem 2008;21:183-192.

39 Foller M, Sopjani M, Koka S, Gu S, Mahmud H, Wang K, Floride E, Schleicher E, Schulz E, Munzel T, Lang F: Regulation of erythrocyte survival by AMP-activated protein kinase. FASEB J 2009;23:1072-1080.

40 Brugnara C, de Franceschi L, Alper SL: Inhibition of $\mathrm{Ca}(2+)$-dependent $\mathrm{K}+$ transport and cell dehydration in sickle erythrocytes by clotrimazole and other imidazole derivatives. J Clin Invest 1993;92:520-526.

41 Lang PA, Kaiser S, Myssina S, Wieder T, Lang F, Huber SM: Role of Ca2+-activated K+ channels in human erythrocyte apoptosis. Am J Physiol Cell Physiol 2003;285:C1553-C1560.

42 Berg CP, Engels IH, Rothbart A, Lauber K, Renz A, Schlosser SF, Schulze-Osthoff K, Wesselborg S: Human mature red blood cells express caspase- 3 and caspase-8, but are devoid of mitochondrial regulators of apoptosis. Cell Death Differ 2001;8:1197-1206.

43 Lang F, Gulbins E, Lang PA, Zappulla D, Foller M: Ceramide in suicidal death of erythrocytes. Cell Physiol Biochem 2010;26:21-28.

44 Lang PA, Kempe DS, Tanneur V, Eisele K, Klarl BA, Myssina S, Jendrossek V, Ishii S, Shimizu T, Waidmann M, Hessler G, Huber SM, Lang F, Wieder T: Stimulation of erythrocyte ceramide formation by platelet-activating factor. J Cell Sci 2005;118:1233-1243.

45 Klarl BA, Lang PA, Kempe DS, Niemoeller OM, Akel A, Sobiesiak M, Eisele K, Podolski M, Huber SM, Wieder T, Lang F: Protein kinase C mediates erythrocyte "programmed cell death" following glucose depletion. Am J Physiol Cell Physiol 2006;290:C244-C253.

46 Bratosin D, Estaquier J, Petit F, Arnoult D, Quatannens B, Tissier JP, Slomianny C, Sartiaux C, Alonso C, Huart JJ, Montreuil J, Ameisen JC: Programmed cell death in mature erythrocytes: a model for investigating death effector pathways operating in the absence of mitochondria. Cell Death Differ 2001;8:1143-1156.

47 Mandal D, Moitra PK, Saha S, Basu J: Caspase 3 regulates phosphatidylserine externalization and phagocytosis of oxidatively stressed erythrocytes. FEBS Lett 2002;513:184-188.

48 Gatidis S, Zelenak C, Fajol A, Lang E, Jilani K, Michael D, Qadri SM, Lang F: p38 MAPK activation and function following osmotic shock of erythrocytes. Cell Physiol Biochem 2011;28:1279-1286.

49 Zelenak C, Eberhard M, Jilani K, Qadri SM, Macek B, Lang F: Protein Kinase CK1alpha Regulates Erythrocyte Survival. Cell Physiol Biochem 2012;29:171-180.

50 Chen Y, Wu X, Yu S, Fauzee NJ, Wu J, Li L, Zhao J, Zhao Y: Neuroprotective Capabilities of Tanshinone IIA against Cerebral Ischemia/Reperfusion Injury via Anti-apoptotic Pathway in Rats. Biol Pharm Bull 2012;35:164170 .

51 Chien SY, Kuo SJ, Chen YL, Chen DR, Cheng CY, Su CC: Tanshinone IIA inhibits human hepatocellular carcinoma J5 cell growth by increasing Bax and caspase 3 and decreasing CD31 expression in vivo. Mol Med Report 2012;5:282-286.

52 Qiao Z, Ma J, Liu H: Evaluation of the antioxidant potential of Salvia miltiorrhiza ethanol extract in a rat model of ischemia-reperfusion injury. Molecules 2011;16:10002-10012.

53 Su CC, Chien SY, Kuo SJ, Chen YL, Cheng CY, Chen DR: Tanshinone IIA inhibits human breast cancer MDA-MB231 cells by decreasing LC3-II, Erb-B2 and NF-kappaBp65. Mol Med Report 2012;5:1019-1022.

54 Xu S, Little PJ, Lan T, Huang Y, Le K, Wu X, Shen X, Huang H, Cai Y, Tang F, Wang H, Liu P: Tanshinone II-A attenuates and stabilizes atherosclerotic plaques in apolipoprotein-E knockout mice fed a high cholesterol diet. Arch Biochem Biophys 2011;515:72-79.

55 Zhang Y, Won SH, Jiang C, Lee HJ, Jeong SJ, Lee EO, Zhang J, Ye M, Kim SH, Lu J: Tanshinones from Chinese Medicinal Herb Danshen (Salvia miltiorrhiza Bunge) Suppress Prostate Cancer Growth and Androgen Receptor Signaling. Pharm Res 2012;

56 Lang KS, Duranton C, Poehlmann H, Myssina S, Bauer C, Lang F, Wieder T, Huber SM: Cation channels trigger apoptotic death of erythrocytes. Cell Death Differ 2003;10:249-256.

57 Ganapathy V, Thangaraju M, Prasad PD: Nutrient transporters in cancer: relevance to Warburg hypothesis and beyond. Pharmacol Ther 2009;121:29-40.

58 Yoon Y, Kim YO, Jeon WK, Park HJ, Sung HJ: Tanshinone IIA isolated from Salvia miltiorrhiza BUNGE induced apoptosis in HL60 human premyelocytic leukemia cell line. J Ethnopharmacol 1999;68:121-127. 


\section{Cellular Physiology Cell Physiol Biochem 2012;30:282-294 \\ \begin{tabular}{ll|l} 
and BiOchemistry & $\begin{array}{l}\text { DOI: 10.1159/000339064 } \\
\text { Published online: June 19, } 2012\end{array}$ & $\begin{array}{l}\text { (c) 2012 S. Karger AG, Basel } \\
\text { www.karger.com/cpb }\end{array}$ \\
\cline { 2 - 3 } & Zelenak/Pasham/Jilani et al.: Tanshinone IIA Induced Eryptosis
\end{tabular}}

59 Lang KS, Myssina S, Brand V, Sandu C, Lang PA, Berchtold S, Huber SM, Lang F, Wieder T: Involvement of ceramide in hyperosmotic shock-induced death of erythrocytes. Cell Death Differ 2004;11:231-243.

60 Bookchin RM, Ortiz OE, Lew VL: Activation of calcium-dependent potassium channels in deoxygenated sickled red cells. Prog Clin Biol Res 1987;240:193-200.

61 Yang Y, Cai F, Li PY, Li ML, Chen J, Chen GL, Liu ZF, Zeng XR: Activation of high conductance Ca(2+)-activated $\mathrm{K}(+)$ channels by sodium tanshinoneII-A sulfonate (DS-201) in porcine coronary artery smooth muscle cells. Eur J Pharmacol 2008;598:9-15.

62 Arino T, Tanonaka K, Kawahara Y, Maki T, Takagi N, Yagi A, Takeo S: Effects of tanshinone VI on phosphorylation of ERK and Akt in isolated cardiomyocytes and cardiac fibroblasts. Eur J Pharmacol 2008;580:298-305.

63 Cheng CY, Su CC: Tanshinone IIA inhibits Hep-J5 cells by increasing calreticulin, caspase 12 and GADD153 protein expression. Int J Mol Med 2010;26:379-385.

64 Zhang R, Sun J, Ma L, Wu X, Pan G, Hao H, Zhou F, A J, Liu C, Ai H, Shang L, Gao H, Peng Y, Wan P, Wu H, Wang G: Induction of cytochromes P450 1A1 and 1A2 by tanshinones in human HepG2 hepatoma cell line. Toxicol Appl Pharmacol 2011;252:18-27.

65 Wang X, Yeung JH: Inhibitory effect of tanshinones on rat CYP3A2 and CYP2C11 activity and its structureactivity relationship. Fitoterapia 2011;82:539-545.

66 Fang ZY, Lin R, Yuan BX, Yang GD, Liu Y, Zhang H: Tanshinone IIA downregulates the CD40 expression and decreases MMP-2 activity on atherosclerosis induced by high fatty diet in rabbit. J Ethnopharmacol 2008;115:217-222.

67 Kempe DS, Lang PA, Duranton C, Akel A, Lang KS, Huber SM, Wieder T, Lang F: Enhanced programmed cell death of iron-deficient erythrocytes. FASEB J 2006;20:368-370.

68 Birka C, Lang PA, Kempe DS, Hoefling L, Tanneur V, Duranton C, Nammi S, Henke G, Myssina S, Krikov M, Huber SM, Wieder T, Lang F: Enhanced susceptibility to erythrocyte "apoptosis" following phosphate depletion. Pflugers Arch 2004;448:471-477.

69 Lang PA, Beringer O, Nicolay JP, Amon O, Kempe DS, Hermle T, Attanasio P, Akel A, Schafer R, Friedrich B, Risler T, Baur M, Olbricht CJ, Zimmerhackl LB, Zipfel PF, Wieder T, Lang F: Suicidal death of erythrocytes in recurrent hemolytic uremic syndrome. J Mol Med 2006;84:378-388.

70 Kempe DS, Akel A, Lang PA, Hermle T, Biswas R, Muresanu J, Friedrich B, Dreischer P, Wolz C, Schumacher U, Peschel A, Gotz F, Doring G, Wieder T, Gulbins E, Lang F: Suicidal erythrocyte death in sepsis. J Mol Med 2007;85:273-281.

71 Lang PA, Kasinathan RS, Brand VB, Duranton C, Lang C, Koka S, Shumilina E, Kempe DS, Tanneur V, Akel A, Lang KS, Foller M, Kun JF, Kremsner PG, Wesselborg S, Laufer S, Clemen CS, Herr C, Noegel AA, Wieder T, Gulbins E, Lang F, Huber SM: Accelerated clearance of Plasmodium-infected erythrocytes in sickle cell trait and annexin-A7 deficiency. Cell Physiol Biochem 2009;24:415-428.

72 Siraskar B, Ballal A, Bobbala D, Foller M, Lang F: Effect of amphotericin B on parasitemia and survival of plasmodium berghei-infected mice. Cell Physiol Biochem 2010;26:347-354.

73 Bobbala D, Alesutan I, Foller M, Huber SM, Lang F: Effect of anandamide in Plasmodium Berghei-infected mice. Cell Physiol Biochem 2010;26:355-362.

74 Foller M, Bobbala D, Koka S, Huber SM, Gulbins E, Lang F: Suicide for survival--death of infected erythrocytes as a host mechanism to survive malaria. Cell Physiol Biochem 2009;24:133-140.

75 Koka S, Bobbala D, Lang C, Boini KM, Huber SM, Lang F: Influence of paclitaxel on parasitemia and survival of Plasmodium berghei infected mice. Cell Physiol Biochem 2009;23:191-198.

76 Lang PA, Schenck M, Nicolay JP, Becker JU, Kempe DS, Lupescu A, Koka S, Eisele K, Klarl BA, Rubben H, Schmid KW, Mann K, Hildenbrand S, Hefter H, Huber SM, Wieder T, Erhardt A, Haussinger D, Gulbins E, Lang F: Liver cell death and anemia in Wilson disease involve acid sphingomyelinase and ceramide. Nat Med 2007;13:164170.

77 Qadri SM, Mahmud H, Lang E, Gu S, Bobbala D, Zelenak C, Jilani K, Siegfried A, Foller M, Lang F: Enhanced suicidal erythrocyte death in mice carrying a loss of function mutation of the Adenomatous Polyposis Coli gene. J Cell Mol Med 2011;

78 Zappulla D: Environmental stress, erythrocyte dysfunctions, inflammation, and the metabolic syndrome: adaptations to CO2 increases? J Cardiometab Syndr 2008;3:30-34.

79 Bhavsar SK, Bobbala D, Xuan NT, Foller M, Lang F: Stimulation of suicidal erythrocyte death by alpha-lipoic acid. Cell Physiol Biochem 2010;26:859-868.

80 Bhavsar SK, Eberhard M, Bobbala D, Lang F: Monensin induced suicidal erythrocyte death. Cell Physiol Biochem 2010;25:745-752. 


\section{Cellular Physiolosy Cell Physiol Biochem 2012;30:282-294 \begin{tabular}{ll|l} 
and BiOChemistry & $\begin{array}{l}\text { DOI: 10.1159/000339064 } \\
\text { Published online: June 19, } 2012\end{array}$ & $\begin{array}{l}\text { (c) 2012 S. Karger AG, Basel } \\
\text { www.karger.com/cpb }\end{array}$ \\
\cline { 2 - 3 } & Zelenak/Pasham/Jilani et al.: Tanshinone IIA Induced Eryptosis
\end{tabular}}

81 Bhavsar SK, Gu S, Bobbala D, Lang F: Janus kinase 3 is expressed in erythrocytes, phosphorylated upon energy depletion and involved in the regulation of suicidal erythrocyte death. Cell Physiol Biochem 2011;27:547556.

82 Braun M, Foller M, Gulbins E, Lang F: Eryptosis triggered by bismuth. Biometals 2009;22:453-460.

83 Eberhard M, Ferlinz K, Alizzi K, Cacciato PM, Faggio C, Foller M, Lang F: FTY720-induced suicidal erythrocyte death. Cell Physiol Biochem 2010;26:761-766.

84 Felder KM, Hoelzle K, Ritzmann M, Kilchling T, Schiele D, Heinritzi K, Groebel K, Hoelzle LE: Hemotrophic mycoplasmas induce programmed cell death in red blood cells. Cell Physiol Biochem 2011;27:557-564.

85 Ghashghaeinia M, Toulany M, Saki M, Bobbala D, Fehrenbacher B, Rupec R, Rodemann HP, Ghoreschi K, Rocken M, Schaller M, Lang F, Wieder T: The NFkB pathway inhibitors Bay 11-7082 and parthenolide induce programmed cell death in anucleated Erythrocytes. Cell Physiol Biochem 2011;27:45-54.

86 Lang E, Jilani K, Zelenak C, Pasham V, Bobbala D, Qadri SM, Lang F: Stimulation of suicidal erythrocyte death by benzethonium. Cell Physiol Biochem 2011;28:347-354.

87 Mahmud H, Foller M, Lang F: Arsenic-induced suicidal erythrocyte death. Arch Toxicol 2009;83:107-113.

88 Mahmud H, Mauro D, Foller M, Lang F: Inhibitory effect of thymol on suicidal erythrocyte death. Cell Physiol Biochem 2009;24:407-414.

89 Mahmud H, Mauro D, Qadri SM, Foller M, Lang F: Triggering of suicidal erythrocyte death by amphotericin B. Cell Physiol Biochem 2009;24:263-270.

90 Nguyen DB, Wagner-Britz L, Maia S, Steffen P, Wagner C, Kaestner L, Bernhardt I: Regulation of phosphatidylserine exposure in red blood cells. Cell Physiol Biochem 2011;28:847-856.

91 Qadri SM, Kucherenko Y, Zelenak C, Jilani K, Lang E, Lang F: Dicoumarol activates Ca2+-permeable cation channels triggering erythrocyte cell membrane scrambling. Cell Physiol Biochem 2011;28:857-864.

92 Qadri SM, Bauer J, Zelenak C, Mahmud H, Kucherenko Y, Lee SH, Ferlinz K, Lang F: Sphingosine but not sphingosine-1-phosphate stimulates suicidal erythrocyte death. Cell Physiol Biochem 2011;28:339-346.

93 Andrews DA, Low PS: Role of red blood cells in thrombosis. Curr Opin Hematol 1999;6:76-82.

94 Closse C, Dachary-Prigent J, Boisseau MR: Phosphatidylserine-related adhesion of human erythrocytes to vascular endothelium. Br J Haematol 1999;107:300-302.

95 Gallagher PG, Chang SH, Rettig MP, Neely JE, Hillery CA, Smith BD, Low PS: Altered erythrocyte endothelial adherence and membrane phospholipid asymmetry in hereditary hydrocytosis. Blood 2003;101:46254627.

96 Pandolfi A, Di Pietro N, Sirolli V, Giardinelli A, Di Silvestre S, Amoroso L, Di Tomo P, Capani F, Consoli A, Bonomini M: Mechanisms of uremic erythrocyte-induced adhesion of human monocytes to cultured endothelial cells. J Cell Physiol 2007;213:699-709.

97 Wood BL, Gibson DF, Tait JF: Increased erythrocyte phosphatidylserine exposure in sickle cell disease: flowcytometric measurement and clinical associations. Blood 1996;88:1873-1880.

98 Chung SM, Bae ON, Lim KM, Noh JY, Lee MY, Jung YS, Chung JH: Lysophosphatidic acid induces thrombogenic activity through phosphatidylserine exposure and procoagulant microvesicle generation in human erythrocytes. Arterioscler Thromb Vasc Biol 2007;27:414-421.

99 Zwaal RF, Comfurius P, Bevers EM: Surface exposure of phosphatidylserine in pathological cells. Cell Mol Life Sci 2005;62:971-988.

100 Kornhuber J, Tripal P, Reichel M, Muhle C, Rhein C, Muehlbacher M, Groemer TW, Gulbins E: Functional Inhibitors of Acid Sphingomyelinase (FIASMAs): a novel pharmacological group of drugs with broad clinical applications. Cell Physiol Biochem 2010;26:9-20. 